Vol. 3 No. 1, Hal 1-5, Oktober 2021

\title{
Analisis Unjuk Kerja Prototype Trainer Lemari Pendingin dengan Variasi Beban Pendinginan
}

\author{
Andi Arifudin*, I Gede Wiratmaja, I Nyoman Pasek Nugraha \\ Progam Studi Pendidikan Teknik Mesin Fakultas Teknik dan Kejuruan \\ Universitas Pendidikan Ganesha, Singaraja, Bali, Indonesia \\ *Penulis korespondensi: andiarifudin02@gmail.com
}

Histori artikel: diserahkan 26 Juni 2021, direviu 15 Juli 2021, direvisi 20 Agustus 2021

\begin{abstract}
This study aimed to find the effect of variations in cooling load on the performance of the prototype trainer refrigerator, which in this refrigerator prototype had never been tested performance. In this study, the experimental method was used. The values sought in this study were the rate of room cooling and the Coefficient of Performance (COP). In this study, the variation of the cooling load used started from temperatures of 300, 350, 400, $450{ }^{\circ} \mathrm{C}$, with 15 repetitions, and the temperature performance used was $1000 \mathrm{C}$. The study results showed that the highest room cooling rate occurred at $300{ }^{\circ} \mathrm{C}$ cooling load variation, namely 0.00265 , and the smallest room cooling rate occurred at $450^{\circ} \mathrm{C}$ cooling load variation, namely 0.00174. The highest Coefficient of Performance (COP) results occurred at a cooling load variation of $450{ }^{\circ} \mathrm{C}$, namely 34.09, and the lowest Coefficient of Performance (COP) occurred at a cooling load variation of $300{ }^{\circ} \mathrm{C}$, namely 29.60. From these results, it can be concluded that the cooling rate of the room was inversely proportional to the increase in cooling load because the more significant the cooling load, the longer the time obtained, resulting in a small room cooling rate. And for the results of the Coefficient of Performance (COP), it was directly proportional to the increase in the cooling load because the more significant the cooling load given, the higher the temperature at $T 1$ and $T 2$, resulting in a significant Coefficient of Performance (COP).
\end{abstract}

Keywords: Prototype trainer refrigerator, Room Cooling Rate, Coefficient of Performance

DOI : https://doi.org/10.18196/jqt.v3i1.12225

WEB : https://journal.umy.ac.id/index.php/qt/article/view/12225

\section{PENDAHULUAN}

Mahasiswa Pendidikan Teknik Mesin merancang prototype trainer lemari pendingin untuk meningkatkan pemahaman mahasiswa khususnya pada konsentrasi pendingin pada mata kuliah perancangan sistem refrigerasi. Rancangan lemari pendingin berbasis 3D ini sudah dimodifikasi sedemikian rupa dan memiliki beberapa komponen utama yang nantinya akan menunjang keberhasilan produk dalam menjalankan fungsinya. Komponenkomponen utama pada prototype trainer lemari pendingin yaitu kompresor, evaporator, kondensor, filter dryer, dan pipa kapiler (Setyawan, 2020). Prototype trainer lemari pendingin ini belum pernah dilakukan pengujian beban pendinginan sehingga perlu dilakukan studi kelayakan dengan pengujian pembebanan agar diketahui data hasil perbandingan COP (Coefficient of Performance), laju pendinginan ruangan dari hasil perbandingan dan laju pendinginan ruangan.

Penelitian-penelitian sebelumnya mengenai beban pendinginan pada mesin pendingin antara lain yaitu dari (Purwanto dan Ridhuan, 2014) meneliti tentang Pengaruh Jenis refrigeran dan Beban Pendinginan Terhadap Kemampuan Kerja Mesin Pendingin type Air Conditioner (AC). Pada penelitian ini diperoleh hasil yaitu pada refrigeran R12 dengan beban 150 watt waktu yang dibutuhkan untuk mencapai suhu 
ideal $\left(23^{\circ} \mathrm{C}\right)$ lebih cepat dibandingan dengan refrigeran R22 yaitu 45 menit sedangkan pada refrigeran R22 dengan beban 150 Watt yaitu 53 menit. Pada refrigeran R12 dengan beban 750 Watt waktu yang dibutuhkan untuk mencapai suhu ideal $\left(23^{\circ} \mathrm{C}\right)$ lebih lama dibandingan dengan refrigeran R22 yaitu 130 menit sedangkan pada refrigeran R22 dengan beban 150 Watt yaitu 93 menit. Penggunaan beban yang kecil (dibawah beban 300 Watt) sebaiknya menggunakan refrigeran R12 dan pada beban yang lebih besar (diatas beban 300 Watt) pada ruangan yang sama menggunakan refrigeran R22 karena lebih cepat dalam waktu pendinginan.

Penelitian yang dilakukan oleh Mastur et al., 2017) meneliti tentang Pengaruh Variasi Beban pendinginan, dari penelitian ini diperoleh hasil yaitu waktu pendinginan dan temperatur ruang terhadap performasi mesin pendingin tipe Air Conditioner. laju aliran massa refrigeran tertinggi pada beban lampu 500 watt yaitu $0,060556 \mathrm{~kg} / \mathrm{s}$, dalam waktu 8 menit. Efek refrigerasi tertinggi pada beban lampu 100 watt yaitu $202,702 \mathrm{~kJ} / \mathrm{kg}$, dalam waktu 20 menit. Daya kompressor tertinggi pada beban lampu 500 watt yaitu $0,701 \mathrm{~kW}$ dalam waktu 8 menit. coefficient of performance tertinggi pada beban lampu 300 watt yaitu $18,27979 \mathrm{~kW}$ dalam waktu 4 menit.

Supriana et al., 2019) meneliti tentang Pengaruh Variasi Fluida Pendingin Terhadap Capaian Suhu Optimal Pada Rancangan Mesin Pendingin Mini Water Chiller hasil dari penelitian ini yaitu AHU 1 untuk fluida air: 13,430 C, coolant: 12,520 C dan campuran air + coolant: 11,520 C, AHU 2 untuk fluida air: 13,330 C, coolant: $12,420 \mathrm{C}$ dan campuran air + coolant: 11,420 C dan AHU 3 untuk fluida air: 13,230 C, coolant: 12,320 C dan campuran air + coolant: 11,320 C. Kesimpulan dari penelitian tersebut yaitu fluida campuran air + coolant mendapatkan suhu yang sangat optimal dikarenakan karakteristik yang di miliki fluida air dan fluida coolant.

Putra et al., 2020) meneliti tentang Pengaruh Variasi Beban pendinginan terhadap unjuk kerja prototype mini water chiller, dari penelitian ini diperoleh hasil yaitu laju pendinginan ruangan tertinggi terjadi pada pembebanan dengan temperatur $50^{\circ} \mathrm{C}$ dan laju pendinginan ruangan terendah terjadi pada pembebanan dengan temperatur $30^{\circ} \mathrm{C}$ dan untuk hasil COP tertinggi terjadi pada pembebanan dengan temperatur $30^{\circ} \mathrm{C}$ dan $\mathrm{COP}$ terendah terjadi pada pembebanan dengan temperatur $50^{\circ} \mathrm{C}$.

Pada penelitian sebelumnya proses pembuatan Prorotype trainer lemari pendingin hanya sampai tahap modifikasi sebagai media pembelajaran dalam mata kuliah perancangan refrigrasi yang dimana pada Prorotype trainer lemari pendingin tersebut belum di lakukan uji performasi, oleh karena itu penulis tertarik untuk meneliti lebih lanjut tentang beban pendinginan pada Prorotype trainer lemari pendingin untuk mengetahui performasi pada Prototype trainer lemari pendingin.

\section{METODE}

Pada penelitian ini menggunakan metode eksperimen. Dalam peneliti ini memberikan variasi beban pendinginan pada Prototype trainer lemari pendingin guna mendapatkan hasil nilai coefficient of performance dan laju pendinginan ruangan. Variasi temperatur yang digunakan yaitu $30^{\circ} \mathrm{C}, 35^{\circ} \mathrm{C}, 40^{\circ} \mathrm{C}$ dan $45^{\circ} \mathrm{C}$, dengan acuan suhu standar $10^{\circ} \mathrm{C}$ pada Prototype trainer lemari pendingin. Kemudian dilakukan pengukuran suhu pada pipa tekan keluar dari kompresor sebelum kondensor (T2), selanjutnya saluran pipa yang menuju evaporator setelah pipa kapiler (T4), terakhir pipa hisap yang menuju kompresor setelah evaporator (T1) secara berturut-turut sesuai dengan variasi temperatur dan pengulangan pengujian yang telah ditentukan. Teknik analisa data pada penelitian ini menggunakan teknik statistik deskriptif kuantitatif.

\section{HASIL DAN PEMBAHASAN}

\section{Hasil Data Penelitian Laju Pendinginan Ruangan.}

Pengambilan data pada prototype trainer lemari pendingin diperoleh data hasil penelitian dari laju pendinginan ruangan sebanyak 15 kali pengulangan dengan varasi beban pendinginan ruangan. Dari hasil data tersebut penulis dapat melakukan perhitungan untuk mencari hasil laju pendinginan ruangan dari setiap variasi beban pendinginan. Tabel 1 menyajikan data hasil dari setiap variasi beban pendinginan. 
TABEL 1. Hasil Laju Pendinginan Ruangan Terhadap Variasi Beban Pendinginan

\begin{tabular}{|c|c|c|c|c|}
\hline \multirow[b]{2}{*}{$\begin{array}{c}\text { Pengujian } \\
\text { Ke- }\end{array}$} & \multicolumn{4}{|c|}{ Laju Pendinginan Ruangan ( kj/s) } \\
\hline & $\begin{array}{l}\text { Variasi } \\
\text { Suhu } \\
\text { 30 }^{0} \mathrm{C}\end{array}$ & $\begin{array}{l}\text { Variasi } \\
\text { Suhu } \\
\mathbf{3 5}^{\circ} \mathrm{C}\end{array}$ & $\begin{array}{l}\text { Variasi } \\
\text { Suhu } \\
40^{\circ} \mathrm{C}\end{array}$ & $\begin{array}{l}\text { Variasi } \\
\text { Suhu } \\
4^{0} \mathrm{C}\end{array}$ \\
\hline 1 & 0,00280 & 0,00265 & 0,00207 & 0,00173 \\
\hline 2 & 0,00270 & 0,00247 & 0,00204 & 0,00177 \\
\hline 3 & 0,00 & 0,002 & & 0,00177 \\
\hline 4 & 0,00269 & 0,00251 & 0,00203 & 0,00176 \\
\hline 5 & 0,00264 & 0,00257 & 0,00207 & 0,00175 \\
\hline 6 & 0,00259 & 0,00245 & 0,002 & 0,00173 \\
\hline 7 & 0,002 & 0,002 & 0,0 & \\
\hline 8 & 0,00263 & 0,00255 & 0,00208 & 0,00174 \\
\hline 9 & 0,00260 & 0,00253 & 0,00208 & 0,00175 \\
\hline 10 & 0,00251 & 0,00248 & 0,00207 & 0,00174 \\
\hline 11 & 0,00264 & 0,00246 & 0,00204 & 0,00174 \\
\hline 12 & 0,00273 & 0,00257 & 0,00202 & 0,00173 \\
\hline 13 & 0,00262 & 0,00252 & 0,00206 & 0,00172 \\
\hline 14 & 0,00261 & 0,00258 & 0,00209 & 0,00173 \\
\hline 15 & 0,00263 & 0,00253 & 0,00205 & 0,00173 \\
\hline Rata -rata & 0,00265 & 0,00253 & 0,00206 & 0,00174 \\
\hline
\end{tabular}

Gambar 1 menunjukkan tentang laju pendinginan ruangan pada prototype trainer lemari pendingin dengan variasi beban pendinginan, terlihat pada grafik tersebut yaitu variasi beban pendinginan suhu $30^{\circ} \mathrm{C}$ menghasilkan laju pendinginan ruangan $0,00265(\mathrm{kj} / \mathrm{s})$, suhu $35^{\circ} \mathrm{C}$ menghasilkan laju pendinginan ruangan $0,00253(\mathrm{kj} / \mathrm{s})$, suhu $40^{\circ} \mathrm{C}$ menghasilkan laju pendinginan ruangan $0,00208(\mathrm{kj} / \mathrm{s})$ dan suhu $45^{\circ} \mathrm{C}$ menghasilkan laju pendinginan ruangan $0,00174(\mathrm{kj} / \mathrm{s})$. Adapun hasil laju pendinginan ruangan standar (tanpa beban pendinginan) yaitu $0,00432(\mathrm{kj} / \mathrm{s})$, terlihat dari perbandingan hasil laju pendinginan ruangan standar mengalami penurunan pada setiap variasi beban pendinginan.

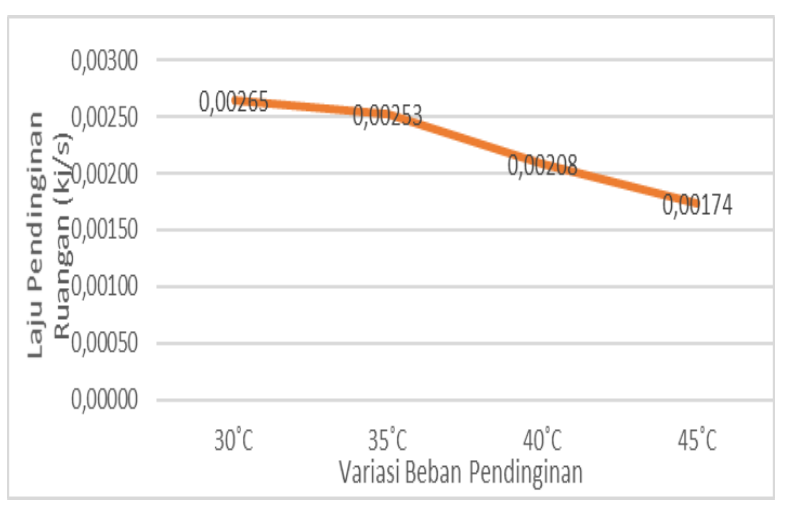

GAMBAR 1. Grafik Perbandingan Laju

Pendinginan Ruangan Pada Prototype Trainer Lemari Pendingin
Pada variasi beban pendinginan suhu $30^{\circ} \mathrm{C}$ yaitu terjadi penurunan laju pendinginan ruangan 38,67\%, Pada variasi beban pendinginan suhu $35^{\circ} \mathrm{C}$ yaitu terjadi penurunan laju pendinginan ruangan $41,43 \%$, Pada variasi beban pendinginan suhu $40^{\circ} \mathrm{C}$ yaitu terjadi penurunan laju pendinginan ruangan $51,85 \%$, Pada variasi beban pendinginan suhu $45^{\circ} \mathrm{C}$ yaitu terjadi penurunan laju pendinginan ruangan $59,72 \%$. beban pendinginan yang diberikan maka memerlukan waktu yang lebih lama untuk mencapai suhu yang ditentukan singga menghasilkan laju pendinginan ruangan yang berbeda pada setiap variasi beban pendinginan.

Dilihat dari hasil perhitungan persentase laju pendinginan ruangan pada Prototype trainer lemari pendingin mengalami penurunan pada setiap variasi beban pendinginan oleh karena itu laju pendinginan ruangan berbanding terbalik dengan peningkatan variasi beban pendinginan dimana semakin besar beban pendinginan maka hasil laju pendinginan ruangan mengalami penurunan yang berbeda dikarenakan semakin besar beban pendinginan yang diberikan maka memerlukan waktu yang lebih lama untuk mencapai suhu $10^{\circ} \mathrm{C}$ oleh karena itu menghasilkan laju pendinginan ruangan yang rendah dan begitu juga sebaliknya semakin kecil beban pendinginan yang diberikan maka memerlukan waktu yang lebih singkat untuk mencapai suhu $10^{\circ} \mathrm{C}$ oleh karena itu menghasilkan laju pendinginan ruangan yang besar. Hal ini selaras dengan hasil penelitian yang dilakukan oleh Putra et al., (2020) dimana variasi beban pendinginan sebesar suhu $30^{\circ} \mathrm{C}$, $35^{\circ} \mathrm{C}, \quad 40^{\circ} \mathrm{C}, \quad 45^{\circ} \mathrm{C}$, dan $50^{\circ} \mathrm{C}$ berpengaruh terhadap laju pendinginan ruangan dimana semakin besar beban pendinginan yang diberikan maka memerlukan waktu yang lebih lama untuk mencapai suhu yang ditentukan singga menghasilkan laju pendinginan ruangan yang berbeda pada setiap variasi beban pendinginan

\section{Hasil Data Penelitian Coefficient of Perfomance}

Setelah penulis melakukan proses pengambilan data pada prototype trainer lemari pendingin dan diperoleh data hasil penelitian dari COP sebanyak 15 kali pengulangan dengan varasi beban pendinginan ruangan. Dari hasil data tersebut penulis dapat melakukan perhitungan untuk mencari COP untuk setiap variasi beban 
pendinginan ruangan. Tabel 2 menyajikan data hasil COP dari setiap variasi beban pendinginan.

TABEL 2. Rata - Rata Hasil Coefficient of Perfomance Terhadap Variasi Beban Pendinginan

\begin{tabular}{ccccc}
\hline \multicolumn{5}{c}{ Coefficient of Perfomance (COP) } \\
\hline $\begin{array}{c}\text { Pengujian } \\
\text { Ke- }\end{array}$ & $\begin{array}{c}\text { Variasi } \\
\text { Suhu } \\
\mathbf{3 0}^{\mathbf{0}} \mathbf{C}\end{array}$ & $\begin{array}{c}\text { Variasi } \\
\text { Suhu } \\
\mathbf{3 5}^{\mathbf{0}} \mathbf{C}\end{array}$ & $\begin{array}{c}\text { Variasi } \\
\text { Suhu } \\
\mathbf{4 0}^{\mathbf{0}} \mathbf{C}\end{array}$ & $\begin{array}{c}\text { Variasi } \\
\text { Suhu } \\
\mathbf{4 5}^{\mathbf{0}} \mathbf{C}\end{array}$ \\
\hline 1 & 33,95 & 28,22 & 26,48 & 34,72 \\
\hline 2 & 33,56 & 29,04 & 24,68 & 33,94 \\
\hline 3 & 26,49 & 28,71 & 44,65 & 35,72 \\
\hline 4 & 26,69 & 30,55 & 34,81 & 32,12 \\
\hline 5 & 25,97 & 31,68 & 28,56 & 27,98 \\
\hline 6 & 34 & 30,56 & 31,66 & 38,32 \\
\hline 7 & 28,64 & 29,53 & 34,98 & 38,32 \\
\hline 8 & 25,98 & 28,83 & 56,82 & 34,07 \\
\hline 9 & 28,89 & 30,43 & 25,45 & 36,50 \\
\hline 10 & 32,35 & 30,67 & 30,21 & 31,25 \\
\hline 11 & 32,63 & 28,08 & 49,39 & 33,67 \\
\hline 12 & 29,51 & 27,60 & 53,36 & 33,69 \\
\hline 13 & 32,05 & 31,03 & 26,51 & 32,50 \\
\hline 14 & 29,26 & 27,59 & 29,52 & 37,51 \\
\hline 15 & 33,95 & 28,22 & 26,48 & 34,72 \\
\hline Rata -rata & 29,60 & 29,81 & 33,34 & 34,09 \\
\hline
\end{tabular}

Gambar 2 menunjukkan rata-rata COP pada prototype trainer lemari pendingin dengan variasi beban pendinginan, terlihat meningkat secara bertahap yaitu COP suhu $30^{\circ} \mathrm{C}(29,60)$, COP suhu $35^{\circ} \mathrm{C}(29,81)$, COP suhu $40^{\circ} \mathrm{C}$ $(33,34)$, dan COP suhu $45^{\circ} \mathrm{C}(34,09)$. Adapun hasil COP standar (tanpa beban pendinginan) yaitu 26,97, terlihat dari perbandingan hasil COP standar mengalami penurunan pada setiap variasi beban pendinginan, Pada variasi beban pendinginan suhu $30^{\circ} \mathrm{C}$ terjadi peningkatan COP $9,75 \%$, variasi beban pendinginan suhu $35^{\circ} \mathrm{C}$ terjadi peningkatan COP $10,53 \%$, variasi beban pendinginan suhu $40^{\circ} \mathrm{C}$ terjadi peningkatan COP $23,62 \%$, dan pada variasi beban pendinginan suhu $45^{\circ} \mathrm{C}$ terjadi peningkatan COP sebesar 26,40\%.

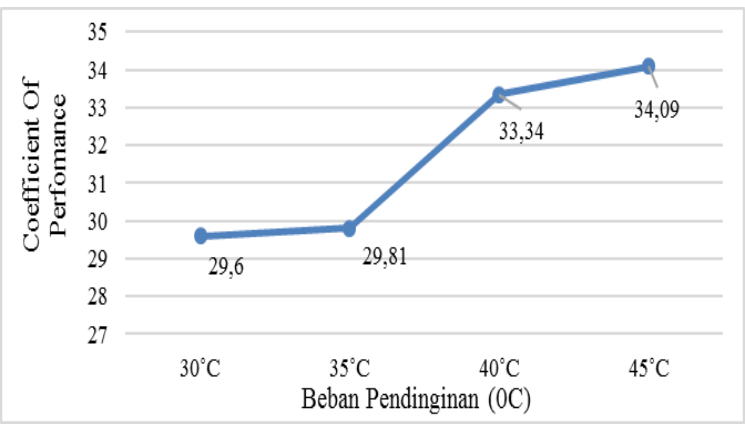

GAMBAR 2. Grafik Pengaruh Coefficient of Perfomance Terhadap Variasi Beban Pendinginan
Berdasarkan hasil perhitungan prosentase, dapat dilihat bahwa Coefficient of Perfomance berbanding lurus dengan peningkatan beban pendinginan (Purnomo et al., 2020). dimana semakin besar beban yang diberikan maka nilai COP semakin besar dikarenakan semakin besar beban pendinginan yang diberikan maka terjadi penyerapan kalor pada evaporator dan kerja kompresor semakin berat sehingga temperatur pada $\mathrm{H} 1$ dan $\mathrm{H} 2$ semakin tinggi dan menghasilan nilai COP yang besar, begitu juga sebalinya semakin kecil beban pendinginan yang diberikan maka kalor yang diserap evaporator makin kecil dan mengakibatkan kerja kompresor yang ringan sehingga temperatur pada $\mathrm{H} 1$ dan $\mathrm{H} 2$ semakin rendah dan menghasilkan nilai COP yang kecil.

\section{KESIMPULAN}

Besarnya laju pendinginan ruangan berbanding terbalik dengan peningkatan pembebanan ruangan dimana seiring dengan meningkatnya pemberian beban pendinginan pada ruangan akan menurunkan laju pendinginan ruangan begitu juga sebaliknya. Parameter COP dapat dilihat berbanding lurus dengan peningkatan pembebanan ruangan dimana seiring dengan meningkatnya pemberian beban pendinginan pada ruangan akan meningkatkan COP dan begitu juga sebaliknya.

\section{DAFTAR PUSTAKA}

Mastur, M., Setiyawan, K., \& Sugiantoro, B. 2017. Pengaruh Variasi Beban, Waktu Pendinginan dan Temperatur Ruang terhadap Performasi Mesin Pendingin. Techno (Jurnal Fakultas Teknik, Universitas Muhammadiyah Purwokerto), 17(1), 043-047.

Purnomo, B. C., Widodo, N., Munahar, S., \& Nugroho, D. 2020. Karakteristik Refrigeran Musicool Dalam Mesin Refrigerasi Kompresi Uap Menggunakan Evaporator Ganda. Quantum Teknika: Jurnal Teknik Mesin Terapan, 1(2), 4854.

Purwanto, E., \& Ridhuan, K. 2014. Pengaruh Jenis Refrigerant Dan Beban Pendinginan Terhadap Kemampuan Kerja Mesin Pendingin. 2014. Turbo: Jurnal Program Studi Teknik Mesin, 3(1), 
11-16.

DOI: http://dx.doi.org/10.24127/trb.v3i1.

19

Putra, R. P. 2020. Analisis Pengaruh Variasi Beban Pendinginan Ruangan terhadap Unjuk Kerja Prototype Mini Water Chiller (Undergraduate thesis, Universitas Pendidikan Ganesha).

Setyawan, T. 2020. Pengembangan Alat Peraga Lemari Pendingin sebagai Media Pembelajaran pada Mata Kuliah Perancangan Sistem Refrigerasi (Undergraduate thesis, Universitas Pendidikan Ganesha).

Supriana, P. D., Dantes, K. R., \& Nugraha, I. N. P. 2019. Pengaruh Variasi Fluida Pendingin terhadap Capaian Suhu Optimal pada Rancangan Mesin Pendingin Mini Water Chiller. Jurnal Pendidikan Teknik Mesin Undiksha, 7(1), 36-42. 